\title{
SISTEMATIK REVIEW : FAKTOR RESIKO OBESITAS TERHADAP DIABETES MELLITUS TIPE 2 PADA REMAJA
}

\author{
Systematic Review : Obesity Risk Factors fot Type 2 Diabetes Mellitus in Adolescent
}

\section{Barto Mansyah ${ }^{\text {** }}$}

IProdi D.III Keperawatan Jurusan Keperawatan Poltekkes Kemenkes Palangka Raya

*email:bartomansyah@gmail.com

\begin{abstract}
Abstrak
Penyakit degeneratif atau penyakit tidak menular disebabkan ileh perubahan gaya hidup, khususnya perubahan pola makan. Salah satu penyakit degenaratif adalah diabetes mellitus tipe 2 yang ditandai dengan kelainan sekresi indulin yang kurang, resistensi insulin serta kenaikan produksi glukosa di hati. Remaja merupaka periode kritis, kebiasaan diet yang tidak sehat merupakan salah satu perilaku beresiko pada usia remaja serta diet yang tidak sehat pada remaja salah satunya menyebabkan terjadinya obesitas. Obesitas adalah ciri khas dari diabetes mellitus tipe 2 dan kebanyakan remaja dengan diabetes mellitus tipe 2 mengalami obesitas saat didiagnosis. Penelitian ini merupakan penelitian sistematik review dengan metodologi pencarian artikel melalui mesin pencarian google scholar, PubMed dan elsevier dengan kata kunci Obesitas sebagai Faktor Resiko terjadinya diabetes mellitus tipe II pada remaja dimana terdapat 12 artikel penelitian yang diidentifikasi dan diketahui bahwa obsesitas pada remaja merupakan faktor resiko terjadinya diabetes mellitus tipe 2 di masa dewasa. Pentingnya memberikan edukasi yang fokus terhadap perubahan gaya hidup yang bertujuan untuk mengurangi tingkat kelebidan berat badan dan obesitas dimasa anak dan remaja serta edukasi juga diberikan kepada seluruh anggota keluarga agar keluarga memahami pentingnya perubahan gaya hidup untuk keberhasilan manajemen diabetes mellitus tipe 2 .
\end{abstract}

Kata Kunci:

Diabetes Mellitus Tipe

Remaja

Keywords:

Type 2 diabetes

Adolescents

\begin{abstract}
Degenerative diseases or non-communicable diseases are caused by changes in lifestyle, especially changes in diet. One of the degenerative diseases is type 2 diabetes mellitus, which is characterized by insufficient insulin secretion, insulin resistance and increased glucose production in the liver. Adolescence is a critical period, unhealthy dietary habits are one of the risky behaviors in adolescence and an unhealthy diet in adolescents is one of the causes of obesity. Obesity is a hallmark of type 2 diabetes mellitus and most adolescents with type 2 diabetes mellitus are obese at diagnosis. This study is a systematic review study with article search methodology through the search engines Google Scholar, PubMed and Elsevier with the keywords Obesity as a Risk Factor for Type II Diabetes Mellitus in adolescents where there are 12 research articles identified and it is known that obsession in adolescents is a risk factor for the occurrence of diabetes mellitus. type 2 diabetes mellitus in adulthood. The importance of providing education that focuses on lifestyle changes that aim to reduce the level of overweight and obesity in children and adolescents as well as education is also given to all family members so that families understand the importance of lifestyle changes for the successful management of type 2 diabetes mellitus.
\end{abstract}

\section{PENDAHULUAN}

Diabetes mellitus merupakan masalah kesehatan masyarakat yang utama. Diabetes mellitus mencakup sederatan penyakit metabolik yang ditandai dengan hiperglikemia akibat defek pada aksi insulin, sekresi insulin atau keduanya. Efek diabetes antara lain kerusakan jangka panjang, disfungsi dan kegagalan berbagai organ terutama mata, ginjal, saraf, jantung dan pembuluh darah (Agrimon, 20l4). Diabetes mellitus terdiri dari dua kategori utama salah satunya adalah diabetes mellitus tipe 2 dimana lebih dari 90\% kasus diabetes mellitus adalah diabetes tipe 2. Penyakit 
diabetes merupakan penyakit degeneratif yang berbahaya dan awalnya asimtomatik yang menyebakan orang tidak mencari perhatian medis secara dini sehingga $30-85 \%$ kasus diabetes tipe 2 tidak terdiagnosis dan pada akhirnya sekitar $20 \%$ kasus akan mengalami komplikasi (Samson \& Garber, 2018).

Hasil Riskesdas tahun 2007 responden yang diperiksa kadar glukosanya 5,7\% menderita diabetes mellitus yang terdeteksi 26,3\% yang telah terdiagnosis sebelumnya dan $73,7 \%$ tidak terdiagnosis sebelumnya (Kemenkes RI, 20I4). Kemudian pada tahun 2013 dari $6,9 \%$ penderita diabetes mellitus yang didapatkan $30,4 \%$ yang telah terdiagnosis sebelumnya dan $69,6 \%$ tidak terdiagnosis sebelumnya meskipun terjadi peningkatan proporsi penderita diabetes mellitus yang terdiagnosis namun proporsi yang tidak terdiagnosis sebelumnya masih besar (Kemenkes RI, 2019).

Pada tahun 2014 secara global memperkirakan 422 juta orang dewasa dengan diabetes dibandingkan dengan tahun 1980 sebesar 108 juta. Prevalensi diabetes di dunia telah meningkat hampir dua kali lipat yaitu 4,7\% menjadi $8,5 \%$ pada populasi orang dewasa sejak tahun 1980. Hal ini mencerminkan peningkatan faktor resiko terkait seperti kelebihan berat badan atau obesitas dan prevalensi diabetes meningkat lebih cepat di negara berpenghasilan rendah dan menengah dibandingkan negara berpenghasilan tinggi. Diabetes menyebabkan I,5 juta kematian pada tahun 20I2. Kadar glukosa yang lebih tinggi dari normal mengakibatkan tambahan 2,2 juta kematian dengan meningkatkan resiko penyakit kardiovaskuler dan lainnya (Kemenkes RI, 2019).

Etiologi bentuk umum diabetes mellitus tipe 2 adalah multifktorial dan melibatkan interaksi yang kompleks antara genetik, epigenetik dan faktor lingkungan dan peran lingkungan yang berpengaruh khususnya pola makan dan gaya hidup (Berends et al., 20I2). Kajian berbagai penelitian menunjukkan bahwa penderita diabetes mellitus tipe 2 memerlukan penguatan edukasi diabetes mellitus termasuk pengelolaan pola makan untuk mendorong pemahaman pengelolaan penyakit dengan lebih baik untuk perawatan diri yang lebih tepat dan kualitas yang lebih baik (Sami et al., 2017). Faktor resiko diabetes mellitus yang tidak dapat dimodifikasi adalah ras dan etnik, umur, jenis kelamin, riwayat keluarga dengan diabetes mellitus, riwayat melahirkan bayi dengan berat badan lebih dari 4000 gram dan riwayat lahir dengan berat badan lahir rendah sedangkan faktor resiko yang dapat dimodifikasi erat kaitannya dengan perilaku hidup yang kurang sehat meliputi kurangnya aktivitas fisik, berat badan lebih (obesitas), hipertensi, dislipidemia, diet tidak sehat, riwayat toleransi glukosa terganggu (TGT) dan merokok (Kemenkes RI, 20I4).

Selain penyakit kardiovaskuler, diabetes salah satu penyebab utama penyakit ginjal dan kebutaan serta diabetes menjadi penyebab terjadinya amputasi yang bukan disebabkan oleh trauma. Dampak lain dari diabetes adalah mengurangi usia harapan hidup sebesar 5-10 tahun dan usia harapan hidup penderita diabetes mellitus tipe 2 dengan penyakit mental serius bahkan $20 \%$ lebih rendah dibandingkan dengan populasi umum (Kemenkes RI, 2019). Remaja dan usia sekolah merupakan periode kritis, kebiasaan diet yang tidak sehat merupakan salah satu perilaku beresiko pada usia remaja. Diet yang tidak sehat pada remaja salah satunya menyebabkan obesitas (Eker et al., 2018). Selain itu, hasil penelitian juga menyimpulkan bahwa Indeks massa tubuh (IMT) yang berada pada kriteria overweight dapat berpengaruh pada fungsi reproduksi remaja salah satunya adalah terjadinya peningkatan dismenorea pada remaja (Arisani, 2019).

Obesitas dan diabetes tipe 2 merupakan masalah kesehatan masyarakat. Peningkatan prevalensi diabetes sejalan dengan obesitas dimana peningkatan indeks massa tubuh (IMT) dan lingkar pinggang menunjukkan resiko relatif yang lebih tinggi dengan peningkatan diabetes mellitus tipe 2 dimana periode remaja merupakan periode dalam perkembangan obesitas (Cederberg \& Laakso, 20I4). Obesitas adalah ciri khas dari diabetes mellitus tipe 2 dan kebanyakan remaja 
dengan diabetes mellitus tipe 2 mengalami obesitas atau sangat gemuk saat didiagnosis dan muncul dengan glukosuria, poliuria dan polidipsia dan sedikit atau tidak ada penurunan berat badan. Remaja penderita diabetes mellitus tipe 2 memiliki resiko lebih tinggi untuk komplikasi dibandingkan dengan orang dewasa dengan diabetes mellitus akibatnya berkembang menjadi diabetes mellitus tipe 2 diusia yang lebih muda juga dikaitkan dengan yang jauh lebih tinggi resiko penyakit kardiovaskular jangka panjang dibandingkan mereka yang menderita diabetes mellitus tipe 2 di usia paruh baya (Reinehr, 2016).

\section{METODOLOGI}

Penelitian ini merupakan penelitian sistematik review dengan tema Obesitas sebagai Faktor Resiko terjadinya diabetes mellitus tipe II pada remaja. Sumber data penelitian berasal dari literatur berupa artikel jurnal bereputasi baik nasional maupun internasional yang diperoleh melalui mesin pencarian google scholar, PubMed dan elsevier dengan kata kunci Obesitas sebagai Faktor Resiko terjadinya diabetes mellitus tipe II pada remaja dengan rentang waktu publikasi antara tahun 2015 sampai dengan tahun 2020.

Protokol dalam strategi pencarian literatur menggunakan PRISMA (Preferred Reporting Items for Systematic Review and Meta Analysis) untuk menentukan penyeleksian studi yang telah ditemukan dan disesuaikan dengan tema sistematik review, yaitu Obesitas sebagai Faktor Resiko terjadinya diabetes mellitus tipe II pada remaja. Kriteria inklusi pada penelitian ini adalah artikel penelitian yang memiliki tema Obesitas sebagai Faktor Resiko terjadinya diabetes mellitus tipe II pada remaja dan dapat diakses secara penuh. Artikel penelitian yang memenuhi kriteria inklusi kemudian diekstraksi menjadi beberapa bagian meliputi nama penulis, tahun publikasi, metode penelitian dan temuan utama penelitian.

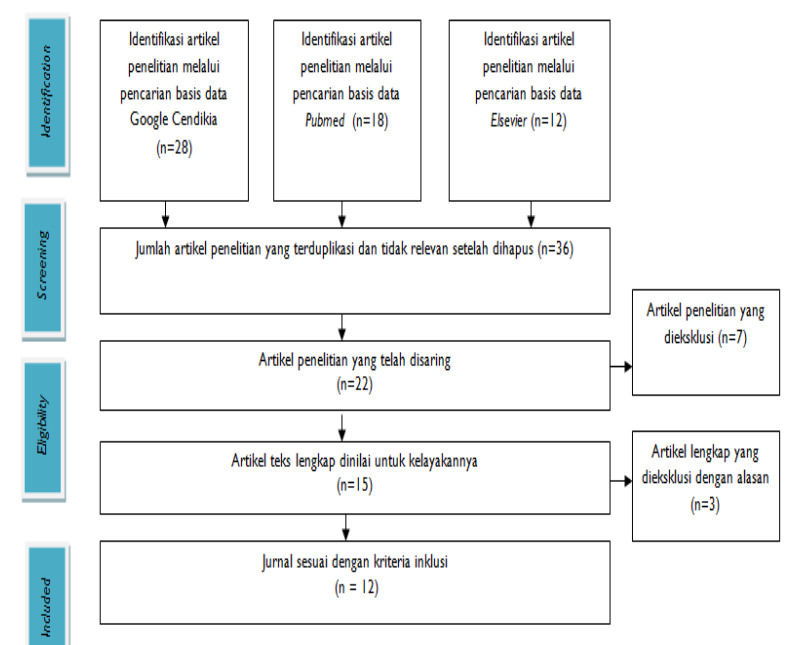

Gambar I. Diagram Alur PRISMA

\section{HASIL DAN PEMBAHASAN}

Berdasarkan dari hasil pencarian artikel diperoleh 12 artikel penelitian yang sesuai dengan kriteria inklusi dengan kata kunci yang telah ditentukan dan dapat diakses secara penuh melalui mesin pencarian google scholar, PubMed dan elsevier dengan kata kunci faktor resiko diabetes mellitus pada remaja dengan rentang waktu publikasi hingga tahun 202I. Berdasarkan tujuan penelitian, maka hasil disampaikan dalam bentuk tabel dan rangkuman artikel penelitian pada tabel dibawah ini :

Tabel I. Ringkasan Artikel tentang Faktor Resiko terjadinya diabetes mellitus tipe II pada remaja

\begin{tabular}{|c|l|l|l|l|}
\hline No & Author, Tahun & \multicolumn{1}{|c|}{ Judul } & \multicolumn{1}{c|}{ Metode } \\
\hline I & Utami et al., (2019) & $\begin{array}{l}\text { An Overview of Physical Activities } \\
\text { among Family Members with Risk of } \\
\text { Type 2 Diabetes Mellitus in } \\
\text { Pekanbaru. }\end{array}$ & $\begin{array}{l}\text { Penelitian deksriptif. } \\
\text { Jumlah sampel I28 } \\
\text { responden yang diambil } \\
\text { dengan teknik purposive } \\
\text { sampling berdasarkan } \\
\text { kriteria inklusi. }\end{array}$ & $\begin{array}{l}\text { Hasil penelitian hampir separuh responden } \\
\text { adalah kelebihan berat badan, sebagian } \\
\text { besar responden memiliki ibu yang } \\
\text { menderita diabetes mellitus tipe 2 dan } \\
\text { aktivitas fisik responden berada pada } \\
\text { kategori aktivitas fisik sedang. Studi ini } \\
\text { merekomendasikan untuk keluarga yang } \\
\text { memiliki resiko diabetes mellitus tipe 2 } \\
\text { untuk memulai hidup yang lebih sehat } \\
\text { dengan menjaga aktivitas fisiknya terutama }\end{array}$ \\
\hline
\end{tabular}




\begin{tabular}{|c|c|c|c|c|}
\hline & & & & $\begin{array}{l}\text { dalam kegiatan olahraga dan memelihara } \\
\text { berat badan. }\end{array}$ \\
\hline 2 & $\begin{array}{l}\text { Kolahdooz et al., } \\
\text { (20।8) }\end{array}$ & $\begin{array}{l}\text { Prevalence of Known Risk Factors } \\
\text { for Type } 2 \text { Diabetes Mellitus in } \\
\text { Multiethnic Urban Youth in } \\
\text { Edmonton: Finding From the WHY } \\
\text { ACT NOW Project. }\end{array}$ & $\begin{array}{l}\text { Cross Sectional study } \\
\text { dengan Kuesioner } \\
\text { dikembangkan } \\
\text { berdasarkan variabel } \\
\text { CANRISK seperti usia, } \\
\text { etnis, jenis kelamin, } \\
\text { riwayat keluarga } \\
\text { diabetes, riwayat } \\
\text { hipertensi, pengukuran } \\
\text { antropometri, aktivitas } \\
\text { fisik dan asupan } \\
\text { makanan. Sampel } \\
\text { penelitian sebanyak } 557 \\
\text { ( } 328 \text { perempuan dan } 229 \\
\text { laki-laki). }\end{array}$ & $\begin{array}{l}\text { Mayoritas remaja memiliki setidaknya } 2 \\
\text { fakto resiko diabetes mellitus tipe } 2 \text {. } \\
\text { Etnisitas merupakan faktor resiko yang } \\
\text { tidak dapat dimodifikasi. Faktor resiko } \\
\text { yang paling umum adalah aktivitas fisik } \\
\text { sehari-hari, kelebihan berat badan atau } \\
\text { obesitas dan konsumsi sayuran dan buah } \\
\text { yang renda merupakan faktor yang dapat } \\
\text { dimodifikasi dengan gaya hidup sehat. }\end{array}$ \\
\hline 3 & $\begin{array}{l}\text { Zimmermann et al., } \\
(2020)\end{array}$ & $\begin{array}{l}\text { Childhood Body Mass Index and } \\
\text { Development of Type } 2 \text { Diabetes } \\
\text { Throughout Adult Life A large Scale } \\
\text { Danis Cohort Study. }\end{array}$ & $\begin{array}{l}\text { Cohort study } \\
\text { menyelidiki nilai body } \\
\text { mass index (BMI) pada } \\
\text { usia } 7-13 \text { tahun dikaitkan } \\
\text { dengan diabetes tipe } 2 \text {. }\end{array}$ & $\begin{array}{l}\text { BMI masa kanak-kanak di bawah rata-rata } \\
\text { tidak terkait dengan diabates mellitus tipe } \\
2 \text { namun BMI diatas rata-rata sangat terkait } \\
\text { dengan diabetes mellitus tipe } 2 \text { dimasa } \\
\text { dewasa dan lebih banyak pada wanita } \\
\text { daripada pria. Ini menambah pembenaran } \\
\text { untuk upaya yang bertujuan untuk } \\
\text { mengurangi tingkat kelebihan berat badan } \\
\text { dan obesitas dimasa anak-anak. }\end{array}$ \\
\hline 4 & Batson et al., (2014) & $\begin{array}{l}\text { A cross-sectional study to } \\
\text { determine the prevalence of obesity } \\
\text { and other risk factors for type } 2 \\
\text { diabetes among school children } \\
\text { inTrinidad, West Indies }\end{array}$ & $\begin{array}{l}\text { Cross sectional } \\
\text { dilakukan diantara anak- } \\
\text { anak sekolah berusia } 7- \\
\text { 18 tahun. Sampek dipilih } \\
\text { secara acak dari } 32 \\
\text { sekolah. }\end{array}$ & $\begin{array}{l}\text { Lebih dari } 40 \% \text { memiliki setidaknya satu } \\
\text { faktor resiko. Strategi yang ditujukan untuk } \\
\text { mengurangi faktor resiko diabetes mellitus } \\
\text { tipe } 2 \text { terutama obesitas. Peningkatan } \\
\text { kesadaran dan intervensi gaya hidup } \\
\text { dengan perhatian khusus pada perubahan } \\
\text { pola makan, fisik, modifikasi aktivitas dan } \\
\text { perilaku merupakan dasar dari setiap } \\
\text { program. }\end{array}$ \\
\hline 5 & Young et al., (2000) & $\begin{array}{l}\text { Chilhood Obesity in a Population at } \\
\text { High Risk for Type } 2 \text { Diabetes. }\end{array}$ & $\begin{array}{l}\text { Cross sectional dengan } \\
\text { total responden } \\
\text { sebanyak } 719 \text { yang } \\
\text { terdiri dari } 354 \text { anak } \\
\text { perempuan dan } 365 \text { anak } \\
\text { laki-laki yang melibatkan } \\
\text { pengukuran } \\
\text { antropometri, kadar } \\
\text { glukosa dan insulin } \\
\text { puasa. }\end{array}$ & $\begin{array}{l}\text { Prevalensi obesitas cukup tinggi yang } \\
\text { terdiri dari } 64 \% \text { perempuan dan } 60 \% \text { laki- } \\
\text { laki melebihi persentil } 85 \text { dan melebihi } \\
\text { ersentil } 95 \text { untuk } 40 \% \text { perempuan dan } 34 \% \\
\text { laki-laki. Indeks massa tubuh adalah } \\
\text { prediktor signifikan dari glukosa dan insulin } \\
\text { pada kedua jenis kelamin terlepas dari usia. } \\
\text { Obesitas berada pada peningkatan resiko } \\
\text { diklasifikasikan sebagai diabetes. Obesitas } \\
\text { merupakan faktor resiko yang kuat. }\end{array}$ \\
\hline 6 & Twig et al., (2020) & $\begin{array}{l}\text { Adolescent Obesity and Early } \\
\text { Onset Type } 2 \text { Diabetes. }\end{array}$ & $\begin{array}{l}\text { Cohort Population- } \\
\text { based study } \\
\text { mengevaluasi I.462.362 } \\
\text { remaja ( } 59 \% \text { laki-laki dan } \\
41 \% \text { usia rata-rata I7,4 } \\
\text { tahun) selama tahun } \\
1996-2016 .\end{array}$ & $\begin{array}{l}\text { Obesitas secara signifikan meningkatkan } \\
\text { resiko kejadian diabetes diawal amsa } \\
\text { dewasa pada kedua jenis kelamin. Obesitas } \\
\text { berat secara signifikan meningkatkan } \\
\text { resiko kejadian diabetes mellitus tipe } 2 \text { di } \\
\text { awal masa dewasa pad akedua jenis } \\
\text { kelamin. Peningkatan obesitas parah } \\
\text { remaja cenderung meningkatkan insiden } \\
\text { diabetes pada orang dewasa muda. }\end{array}$ \\
\hline 7 & Barrett et al., (2013) & $\begin{array}{l}\text { A Cross-sectional Study of Jamaican } \\
\text { Adolescent Risk for Type } 2 \\
\text { diabetes and Cardiovascular } \\
\text { Diseases. }\end{array}$ & $\begin{array}{l}\text { Cross Sectional } \\
\text { terhadap } 276 \text { remaja } \\
\text { Jamaika berusia } 14-19 \\
\text { tahun yang dipilih secara } \\
\text { acak dari kelas } 9 \text { sampai } \\
\text { dengan kelas } 12 \text { dari } 10 \\
\text { sekolah menengah baik } \\
\text { remaja laki-laki maupun } \\
\text { perempuan. }\end{array}$ & $\begin{array}{l}\text { Lebih sepertiga responden kelebihan berat } \\
\text { badan. Remaja putri Jamaika memiliki } \\
\text { jumlah faktor resiko yang secara signifikan } \\
\text { lebih tinggi dan lebih sedikit aktivitas } \\
\text { secara fisik dibandingkan laki-laki }(p<0,05) \text {. } \\
\text { Lebih dari } 80 \% \text { responden melaporkan } 3 \\
\text { faktor resiko untuk diabetes mellitus tipe } 2 \\
\text { dan penyakit kardiovaskuler dan } \\
\text { responden dengan BMI } 24 \text { melaporkan } 5 \\
\text { atau lebih faktor resiko. Remaja Jamaika } \\
\text { beresiko terkena diabetes mellitus tipe } 2 \\
\text { dan penyakit kardiovaskuler. Riwayat } \\
\text { penyekit keluarga dan antropometri } \\
\text { merupakan tindakan mengidentifikasi lebih } \\
\text { banyak remaja yang beresiko dibandingkan } \\
\text { pemeriksaan darah.Langkah-langkah }\end{array}$ \\
\hline
\end{tabular}




\begin{tabular}{|c|c|c|c|c|}
\hline & & & & $\begin{array}{l}\text { intervensi adalah diperlukan untuk } \\
\text { mendidik remaja Jamaika untuk } \\
\text { mengurangi kelebihan berat badan. }\end{array}$ \\
\hline 8 & Lim et al., (2015) & $\begin{array}{l}\text { Association between Obesity } \\
\text { Indices and Insulin Resistance } \\
\text { among Health Korean Adolescent : } \\
\text { The JS High Scholl Study. }\end{array}$ & $\begin{array}{l}\text { Cross Sectional dari } 817 \\
\text { remaja sehat berusia } 15- \\
16 \text { tahun tanpa diabetes. }\end{array}$ & $\begin{array}{l}\text { Penelitian ini menunjukkan bahwa } \\
\text { kelebihan berat badan sedang atau obesitas } \\
\text { berhubungan positif dengan resistensi } \\
\text { insulin yang lebih tinggi pada remaja yang } \\
\text { sehat. Studi prospektif lebih lanjut } \\
\text { diperlukan untuk mengevaluasi } \\
\text { pengendalian berat badan [ada remaja } \\
\text { benar-benar meningkatkan insulin } \\
\text { sensitivitas dan mencegah timbulnya } \\
\text { diabetes. }\end{array}$ \\
\hline 9 & Lukács et al., (20|8) & $\begin{array}{l}\text { Screening Risk Factors for Type } 2 \\
\text { Diabetes in Overweight and Obese } \\
\text { Adolescent in School Settings : A } \\
\text { Population-Based Study. }\end{array}$ & $\begin{array}{l}\text { Cohort Population- } \\
\text { based study } \\
\text { mengeksplorasi proporsi } \\
\text { remaja beresiko untuk } \\
\text { perkembangan diabetes } \\
\text { mellitus tipe } 2 \text {. Sampel } \\
\text { berjumlah } 3962 \text { remaja } \\
\text { dengan BMI Lebih dari } \\
85 \text { persentil. }\end{array}$ & $\begin{array}{l}\text { Proporsi yang tinggi (I3\%) dari remaja } \\
\text { yang kelebihan berat badan berada pada } \\
\text { resiko tinggi untuk berkembang menjadi } \\
\text { diabetes mellitu tipe } 2 \text {. Perbedaan jenis } \\
\text { kelamin diamati dan anak laki-laki lebih } \\
\text { banyak menderita resiko diabetes mellitus } \\
\text { tipe } 2 \text { yang lebih tinggi kemudian I } 3 \% \\
\text { remaja beresiko terkena diabetes mellitus } \\
\text { tipe } 2 \text { dikemudian hari. }\end{array}$ \\
\hline 10 & Qifti et al., 2020 & $\begin{array}{l}\text { Karakteristik Remaja SMA dengan } \\
\text { Faktor Diabetes Mellitus di Kota } \\
\text { Padang. }\end{array}$ & $\begin{array}{l}\text { Deskriptif dengan subjek } \\
\text { penelitain adalah siswa } \\
\text { SMA yang memenuhi } \\
\text { kriteria inklusi sebanyak } \\
\text { I7I orang. Pengumpulan } \\
\text { data dilakukan melalui } \\
\text { skrining berat badan, } \\
\text { tinggi badan serta } \\
\text { pengisian angket data } \\
\text { karakteristik responden. }\end{array}$ & $\begin{array}{l}\text { Sebagian besar remaja berusia I6 tahun, } \\
\text { berjenis kelamin perempuan. Berdasarkan } \\
\text { indeks massa tubuh (IMT) sebagian besar } \\
\text { responden memiliki IMT } \geq 25 \mathrm{~kg} / \mathrm{m}^{2} \text { dan } \\
\text { sebagian besar remaja memiliki riwayat } \\
\text { keluarga dengan Diabetes Mellitus. Penting } \\
\text { bagi remaja dengan faktor resiko untuk } \\
\text { melakukan pemeriksaan gula darah. }\end{array}$ \\
\hline II & $\begin{array}{l}\text { Wabitsch et al., } \\
\text { (2004) }\end{array}$ & $\begin{array}{l}\text { Type } 2 \text { Diabetes Mellitus and } \\
\text { Impaired Glucose Regulation in } \\
\text { Caucasian Children and } \\
\text { Adolescents with Obesity Living in } \\
\text { Germany. }\end{array}$ & $\begin{array}{l}\text { Cohort secara } \\
\text { keseluruhan } 520 \text { anak- } \\
\text { anak dan remaja asal } \\
\text { Kaukasia ( } 237 \text { laki-laki } \\
\text { dan } 283 \text { perempuan) } \\
\text { berusia antara } 8,9 \text { tahun } \\
\text { dan } 20,3 \text { tahun dengan } \\
\text { rata-rata usia I4 tahun. } \\
\text { Semua peserta } \\
\text { mengalami obesitas } \\
\text { dengan BMI diatas } \\
\text { persentil } 97 .\end{array}$ & $\begin{array}{l}\text { Data klinis kelompok studi pasien memiliki } \\
\text { tinggi rata-rata } 165,2 \mathrm{~cm} \text { (kisaran I3I-193), } \\
\text { berat rata-rata } 91,17 \mathrm{~kg} \text { (kisaran 44-164 } \\
\mathrm{kg} \text { ) dan rata-rata BMI } 33,17 \mathrm{~kg} / \mathrm{m}^{2} \text { (kisaran } \\
\left.23,9-5 \mathrm{I}, \mathrm{Ig} / \mathrm{m}^{2}\right) \text { Gangguan regulasi } \\
\text { glukosa dan diabetes mellitus tipe } 2 \text { hadir } \\
\text { dalam jumlah besar dari total responden } \\
\text { yang diteliti. Oleh karena itu skrining untuk } \\
\text { diabetes pada anak dan remaja yang sangat } \\
\text { gemuk direkomendasikan. Pasien yang } \\
\text { diidentifikasi dengan gangguan regulasi } \\
\text { glukosa memerlukan pengobatan khusus } \\
\text { untuk mencegah progresi menjadi } \\
\text { diabetes. }\end{array}$ \\
\hline 12 & $\begin{array}{l}\text { Uçkun-Kitapçi et al., } \\
\text { (2004) }\end{array}$ & $\begin{array}{l}\text { Obesity and Type } 2 \text { Diabetes } \\
\text { Mellitus : A Population Based Study } \\
\text { of Adolescents. }\end{array}$ & $\begin{array}{l}\text { Cross Sectional pada } \\
\text { I } 647 \text { remaja turki untuk } \\
\text { menentukan prevalensi } \\
\text { obesitas, gangguan } \\
\text { glukosa puasa dan } \\
\text { diabetes mellitus tipe } 2 \text {. }\end{array}$ & $\begin{array}{l}\text { Resiko dari obesitas meningkat antara } \\
\text { anak-anak dengan riwayat keluarga } \\
\text { diabetes mellitus atau obesitas dan } \\
\text { diantara responden yang memilki aktivitas } \\
\text { fisik rendah. }\end{array}$ \\
\hline
\end{tabular}

Hasil studi kohort menyimpulkan bahwa BMI masa kanak-kanak di bawah rata-rata tidak terkait dengan diabates mellitus tipe 2 namun BMI diatas rata-rata sangat terkait dengan diabetes mellitus tipe 2 dimasa dewasa dan lebih banyak pada wanita daripada pria. Ini menambah pembenaran untuk upaya yang bertujuan untuk mengurangi tingkat kelebihan berat badan dan obesitas dimasa anak-anak (Zimmermann et al., 2020). Kemudian hasil studi cros sectional menyimpulkan bahwa strategi yang ditujukan untuk mengurangi faktor resiko diabetes mellitus tipe 2 terutama obesitas adalah peningkatan kesadaran dan intervensi gaya hidup dengan perhatian khusus pada perubahan pola makan, fisik, modifikasi aktivitas dan perilaku merupakan dasar dari setiap program (Batson et al., 20I4). Efek dari obesitas terhadap metabolisme glukoa telah terbukti. Anak dengan obesitas lebih beresiko mengalami hiperinsulinemia. Hal ini karena terdapat 
hubungan yang terbalik antara sensitivitas insulin dan lemak visceral. Pengaruh lemak visceral lebih kuat daripada lemak subkutan. Jaringan adiposa yang berkembang pada kondisi obesitas mensintesis dan mensekresi metabolit dan protein (Julia et al., 20I5).

Meningkatnya adipositas yang tercermin dari tingkat indeks massa tubuh (IMT) yang lebih tinggi adalah satusatunya faktor resiko yang paling penting untuk diabetes mellitus tipe 2. Kurangnya aktivitas fisik adalah faktor resiko utama selain itu merokok merupakan hal yang signifikan meningkatkan resiko diabetes mellitus tipe 2. Kemudian faktor genetik merupakan faktor relatif resiko dimana saudara kandung dari pasien dengan diabetes mellitus tipe 2 berkembang menjadi penyakit dibandingkan dengan keluarga dimana tidak ada saudara kandung yang menderita penyakit diabetes mellitus (DeFronzo et al., 20I5). Hasil penelitian hampir separuh responden adalah kelebihan berat badan, sebagian besar responden memiliki ibu yang menderita diabetes mellitus tipe 2 dan aktivitas fisik responden berada pada kategori aktivitas fisik sedang. Studi ini merekomendasikan untuk keluarga yang memiliki resiko diabetes mellitus tipe 2 untuk memulai hidup yang lebih sehat dengan menjaga aktivitas fisiknya terutama dalam kegiatan olahraga dan memelihara berat badan (Utami et al., 2019).

Menurut data dari Global Burden of Disease pandemi global kelebihan berat badan dan obesitas sekarang mempengaruhi $37 \%$ pria, $38 \%$ wanita pada dewasa $\geq$ 20 tahun kemudian $24 \%$ pria dan $23 \%$ wanita pada anak-anak < 20 tahun (Lascar et al., 2018). Obesitas berkorelasi dengan kadar glukosa darah dan pada derajat kriteria indeks massa tubuh $($ IMT) $>23$ dapat menyebabkan peningkatan kadar glukosa darah menjadi 200 mg\% (Fatimah, 20I5). Hasil studi cross sectional menyimpulkan bahwa Prevalensi obesitas cukup tinggi yang terdiri dari $64 \%$ perempuan dan $60 \%$ laki-laki melebihi persentil 85 dan melebihi ersentil 95 untuk $40 \%$ perempuan dan $34 \%$ laki-laki. Indeks massa tubuh adalah prediktor signifikan dari glukosa dan insulin pada kedua jenis kelamin terlepas dari usia. Obesitas berada pada peningkatan resiko diklasifikasikan sebagai diabetes dan obesitas merupakan faktor resiko yang kuat (Young et al., 2000). Dikalangan remaja dan dewasa muda yang pernah didiganosis dengan diabetes selama masa anak-anak atau remaja, prevalensi komplikasi dan komorbiditas lebih tinggi diatara anakanak dan remaja dengan diabetes mellitus tipe 2 dibandingkan diabetes mellitus tipe I (Dabelea et al., 2017) dibandingkan dengan orang yang tidak menderita diabetes, pasien dengan diabetes mellitus tipe 2 memiliki peningkatan resiko sebesar $15 \%$ semua penyebab kematian yang 2 kali lebih tinggi pada orang muda (Chatterjee et al., 2017). Population-based study mengevaluasi I.462.362 remaja (59\% laki-laki dan 4I\% usia rata-rata 17,4 tahun) selama tahun 1996-2016 menyimpulkan bahwa obesitas secara signifikan meningkatkan resiko kejadian diabetes diawal masa dewasa pada kedua jenis kelamin. Obesitas berat secara signifikan meningkatkan resiko kejadian diabetes mellitus tipe 2 di awal masa dewasa pada kedua jenis kelamin. Peningkatan obesitas parah remaja cenderung meningkatkan insiden diabetes pada orang dewasa muda (Twig et al., 2020) dan hasil studi Populationbased study mengeksplorasi proporsi remaja beresiko untuk perkembangan diabetes mellitus tipe 2 denga responden rjumlah 3962 remaja dengan BMI Lebih dari 85 persentil menemukan hasil bahwa Proporsi yang tinggi (13\%) dari remaja yang kelebihan berat badan berada pada resiko tinggi untuk berkembang menjadi diabetes mellitu tipe 2 (Lukács et al., 2018).

Hasil Cross Sectional terhadap 276 remaja berusia 1419 menyimpulkan bahwa Lebih sepertiga responden kelebihan berat badan. Remaja putri Jamaika memiliki jumlah faktor resiko yang secara signifikan lebih tinggi dan lebih sedikit aktivitas secara fisik dibandingkan lakilaki $(p<0,05)$. Lebih dari $80 \%$ responden melaporkan 3 faktor resiko untuk diabetes mellitus tipe 2 dan penyakit kardiovaskuler dan responden dengan BMI 24 melaporkan 5 atau lebih faktor resiko. Langkah-langkah 
intervensi adalah diperlukan untuk mendidik remaja Jamaika untuk mengurangi kelebihan berat badan (Barrett et al., 2013). Diabetes mellitus tipe 2 lebih sering terjadi pada wanita dan remaja wanita dibandingkan pria dan remaja laki-laki. Dalam studi (usia 10-19 tahun) kejadian diabetes mellitus tipe 2 pada wanita hampir 2 kali lipat dari individu laki-laki. Resiko diabetes mellitus tipe 2 secara substansial meningkat pada remaja wanita yang didiagnosis dengan polycystic ovarian syndrome (PCOS) dan mungkin terkait dengan insulin resistensi pada polycystic ovarian syndrome (PCOS) sehingga kejadian diabetes mellitus tipe 2 pada wanita dengan polycystic ovarian syndrome (PCOS) 3 kali lebih tinggi dibandingkan pada populasi umum (Lascar et al., 2018). Pubertas berperan penting dalam perkembangan diabetes mellitus tipe 2 pada anak. Selama pubertas terdapat peningkatan resistensi terhadap aksi insulin sehingga menyebabkan terjadinya hiperinsulinemia. Sesudah pubertas respon insulin basal dan terstimulasi menurun. Peningkatan hormon pertumbuhan pada masa pubertas diduga juga berperan terhadap terjadinya resistensi insulin selama pubertas. Oleh karena itu, tidak mengherankan jika munculnya diabetes mellitus tipe 2 bersamaan dengan usia pertengahan pubertas (Julia et al., 2015).

Faktor yang juga memegang peranan penting dalam terjadinya penyakit diabetes mellitus tipe 2 adalah faktor lingkungan yang meliputi obesitas, makan banyak dan kurangnya aktivitas fisik. Obesitas adalah faktor resiko terjadinya diabetes mellitus tipe 2 (Decroli, 2019). Kemudian kelompok yang beresiko tinggi menderita diabetes mellitus tipe 2 adalah anak atau remaja dengan obesitas, ada keluarga dekat yang menderita diabetes mellitus tipe 2 atau penyakit kardiovaskuler dan ada tanda resistensi insulin (Julia et al., 20I5). Hasil studi deskriptif dengan subjek penelitain adalah siswa SMA yang memenuhi kriteria inklusi sebanyak I7I orang. Pengumpulan data dilakukan melalui skrining berat badan, tinggi badan serta pengisian angket data karakteristik responden diperoleh hasil bahwa sebagian besar responden memiliki IMT $\geq 25 \mathrm{~kg} / \mathrm{m}^{2}$ dan sebagian besar remaja memiliki riwayat keluarga dengan Diabetes Mellitus sehingga penting bagi remaja dengan faktor resiko untuk melakukan pemeriksaan gula darah (Qifti et al., 2020).

Studi epidemiologi menyimpulkan bahwa perilaku, gaya hidup dan biologis merupakan faktor resiko diabetes mellitus tipe 2 (DeFronzo et al., 2015). Faktor yang juga memegang peranan penting dalam terjadinya penyakit diabetes mellitus tipe 2 adalah faktor lingkungan yang meliputi obesitas, makan banyak dan kurangnya aktivitas fisik. Obesitas adalah faktor resiko terjadinya diabetes mellitus tipe 2 (Decroli, 2019). Observasional study menggunakan kueioner dikembangkan berdasarkan variabel CANRISK seperti usia, etnis, jenis kelamin, riwayat keluarga diabetes, riwayat hipertensi, pengukuran antropometri, aktivitas fisik dan asupan makanan dengan Sampel penelitian sebanyak 557 (328 perempuan dan 229 laki-laki) menyimpulkan bahwa Mayoritas remaja memiliki setidaknya 2 faktor resiko diabetes mellitus tipe 2 . Etnisitas merupakan faktor resiko yang tidak dapat dimodifikasi. Faktor resiko yang paling umum adalah aktivitas fisik sehari-hari, kelebihan berat badan atau obesitas dan konsumsi sayuran dan buah yang rendah merupakan faktor yang dapat dimodifikasi dengan gaya hidup sehat (Kolahdooz et al., 2018).

Diabetes melliktus tipe 2 adalah penyakit metabolik kronis yang kompleks dengan etiologi yang heterogen dengan faktor resiko pada tingkat sosial dan kerentanan perilaku, lingkungan dan genetik. Pada anak-anak dan remaja diamati khususnya peningkatan prevalensi diabetes mellitus tipe 2 bersamaan dengan obesitas yang berhubungan dengan resistensi insulin sehingga pendidikan pasien dan keluarga untuk remaja dengan diabetes mellitu tipe 2 sangat penting dan akan fokus pada perubahan perilaku (diet dan aktivitas) (Temneanu et al., 20l6). Hasil studi Cross Sectional dari 817 remaja sehat berusia $15-16$ tahun tanpa 
diabetes menunjukkan bahwa kelebihan berat badan sedang atau obesitas berhubungan positif dengan resistensi insulin yang lebih tinggi pada remaja yang sehat. Studi prospektif lebih lanjut diperlukan untuk mengevaluasi pengendalian berat badan ada remaja benar-benar meningkatkan insulin sensitivitas dan mencegah timbulnya diabetes (Lim et al., 2015). Hasil studi Kohort secara keseluruhan 520 anak-anak dan remaja asal Kaukasia (237 laki-laki dan 283 perempuan) berusia antara 8,9 tahun dan 20,3 tahun dengan ratarata usia 14 tahun dan semua responden mengalami obesitas dengan BMI diatas persentil 97 bahwa gangguan regulasi glukosa dan diabetes mellitus tipe 2 hadir dalam jumlah besar dari total responden yang diteliti. Oleh karena itu skrining untuk diabetes pada anak dan remaja yang sangat gemuk direkomendasikan. Pasien yang diidentifikasi dengan gangguan regulasi glukosa memerlukan pengobatan khusus untuk mencegah progresi menjadi diabetes (Wabitsch et al., 2004).

Terdapat 10 jenis penelitian yang diidentifikasi dan diketahui bahwa obsesitas pada remaja merupakan faktor resiko terjadinya diabetes mellitus tipe $2 \mathrm{di}$ masa dewasa. Pentingnya memberikan edukasi yang fokus terhadap perubahan gaya hidup yang bertujuan untuk mengurangi tingkat kelebidan berat badan dan obesitas dimasa anak dan remaja serta edukasi juga diberikan kepada seluruh anggota keluarga agar keluarga memahami pentingnya perubahan gaya hidup untuk keberhasilan manajemen diabetes mellitus tipe 2 . Hasil penelitian terkait upaya preventif adalah pendidikan kesehatan berupa audio visual efektif dalam meningkatkan pengetahuan dan sikap tentang pola makan terhadap pencegahan penyakit diabetes mellitus tipe 2 sehingga dapat disimpulkan bahwa media pendidikankesehatan audio visual efektif dalam meningkatkan pengetahuan dan sikap remaja tentang pola makan dalam pencegahan penyakit diabetes mellitus tipe 2(Mansyah \& Rahmawati, 202I).
Meski menjadi penyebab obesitas pada anak dan remaja itu kompleks, obesitas jelas merupakan suatau pendorong penting untuk peningkatan prevalensi tipe 2 diabetes mellitus pada orang muda serta perubahan gaya hidup menjadi salah satu faktor terhadap banyaknya peningkatan prevalensi obesitas dan diabetes mellitus tipe 2 . Kurangnya aktivitas fisik dikaitkan dengan peningkatan resiko kegemukan. Kurangnya aktivitas fisik diantara remaja dikaitkan dengan peningkatan resiko sindrom metabolik, resistensi insulin dan diabetes mellitus tipe 2 (Lascar et al., 2018). Kondisi pra-diabetes sering dialami penderita sebelum terjadinya diabetes mellitus tipe 2 dimana pada remaja obesitas kondisi pra diabetes dapat bersifat transien namun bila berat badan sulit dikendalikan sangat beresiko mengalami progesivitas menjadi diabetes mellitus tipe 2 (Julia et al., 2015)

\section{KESIMPULAN}

Peningkatan prevalensi kejadian diabetes mellitus pada remaja yang menunjukkan peningkatan prevalensi obesitas pada remaja. Hal ini semakin jelas bahwa anak dan remaja yang mengalami obesitas dengan tanda klinis resistensi insulin atau kerabat dengan diabetes mellitus tipe 2 diskrining untuk diabetes mellitus tipe 2 . Diabetes Mellitus tipe 2 merupakan penyakit metabolik yang dapat dicegah melalui modifikasi gaya hidup, kontrol diet dan kontrol kelebihan berat badan dan obesitas. Pentingnya memberikan edukasi yang fokus terhadap perubahan gaya hidup daan edukasi juga diberikan kepada seluruh anggota keluarga agar keluarga memahami pentingnya perubahan gaya hidup untuk keberhasilan manajemen diabetes mellitus tipe 2 .

\section{REFERENSI}

I. Agrimon, O. H. (20/4). Exploring the Feasibility of Implementing Self-Management and Patient Empowerment through a Structured Diabetes Education Programme in Yogyakarta City Indonesia: A Pilot Cluster Randomised Controlled Trial. The University of Adelaide, July, I-24. 
https://digital.library.adelaide.edu.au/dspace/bitstre am/2440/87696/8/02whole.pdf

2. Samson, S. L., \& Garber, A. J. (2018). Type 2 diabetes. In Encyclopedia of Endocrine Diseases (Issue January). https://doi.org/10.1016/B978-0-12801238-3.95795-7

3. Kemenkes RI. (20I4). infodatin: Situasi dan Analisis Diabetes.

4. Kemenkes RI. (2019). Hari Diabetes Sedunia Tahun 2018. Pusat Data Dan Informasi Kementrian Kesehatan RI, I-8.

5. Berends, L. M., Hons, B. S., Phil, M., Ozanne, S. E., \& Hons, B. S. (20I2). Best Practice \& Research Clinical Endocrinology \& Metabolism Early determinants of type-2 diabetes. Best Practice \& Research Clinical Endocrinology \& Metabolism, 26(5), 569-580.

https://doi.org/10.1016/j.beem.2012.03.002

6. Sami, W., Ansari, T., Butt, N. S., Rashid, M., \& Hamid, A. (2017). Effect of diet on type 2 diabetes mellitus : A review. I I(2).

7. Eker, H. H., Tașdemir, M., Mercan, S., Mucaz, M., Bektemur, G., Sahinoz, S., \& Ozkaya, E. (2018). Obesity in adolescents and the risk factors. Turkish Journal of Physical Medicine and Rehabilitation, 64(I), 37-45. https://doi.org//0.5606/tftrd.2018.1402

8. Arisani, G. (2019). Hubungan Indeks Massa Tubuh ( IMT ), Kadar Hemoglobin dan Paparan Asap Rokok dengan Kejadian Dismenore. 5(November), I-8.

9. Cederberg, H., \& Laakso, M. (20I4). Obesity and type 2 diabetes. Handbook of Obesity: Epidemiology, Etiology, and Physiopathology, Third Edition, I(4), 539-548. https://doi.org/10.4236/jdm.201 I.14012

10. Reinehr, T. (2016). Type 2 diabetes mellitus in children and adolescents. Australian Family Physician, 45(6), 40I-406. https://doi.org//0.4239/wjd.v4.i6.270

II. Utami, G. T., Woferst, R., \& Lubis, S. L. (2019). An overview of physical activities among family members with risk of type 2 diabetes mellitus in Pekanbaru. Enfermeria Clinica, 29, 26-29.

\section{https://doi.org/10.1016/j.enfcli.2018.11.012}

12. Kolahdooz, F., Nader, F., Daemi, M., Jang, S. L., Ma, N. J., \& Sharma, S. (20l8). Prevalence of Known Risk Factors for Type 2 Diabetes Mellitus in Multiethnic Urban Youth in Edmonton: Findings From the WHY ACT NOW Project. Canadian Journal of Diabetes, 5-10. https://doi.org/10.1016/j.jcjd.2018.10.002

13. Zimmermann, E., Bjerregaard, L. G., Gamborg, M., Vaag, A. A., Sørensen, T. I. A., \& Baker, J. L. (2020). Childhood Body Mass Index and Development of Type 2 Diabetes Throughout Adult Life - A LargeScale Danish Cohort Study. 00(00), I-7. https://doi.org/10.1002/oby.21820

14. Batson, Y. A., Teelucksingh, S., Maharaj, R. G., \& Cockburn, B. N. (20/4). A cross-sectional study to determine the prevalence of obesity and other risk factors for type 2 diabetes among school children in Trinidad, West Indies. Paediatrics and International Child Health, 34(3), 178-183. https://doi.org/10.1 179/20469055 |4Y.00000001 I6

15. Young, T. K., Dean, H. J., Flett, B., \& WoodSteiman, P. (2000). Childhood obesity in a population at high risk for type 2 diabetes. Journal of Pediatrics, 136(3), 365-369. https://doi.org/10.1067/mpd.2000.103504

16. Twig, G., Zucker, I., Afek, A., Cukierman-Yaffe, T., Bendor, C. D., Derazne, E., Lutski, M., Shohat, T., Mosenzon, O., Tzur, D., Pinhas-Hamiel, O., Tiosano, S., Raz, I., Gerstein, H. C., \& Tirosh, A. (2020). Adolescent obesity and early-onset type 2 diabetes. Diabetes Care, 43(7), |487-1495. https://doi.org/10.2337/dc19-1988

17. Barrett, S. C., Huffman, F. G., Johnson, P., Campa, A., Magnus, M., \& Ragoobirsingh, D. (20I3). A cross-sectional study of Jamaican adolescents' risk for type 2 diabetes and cardiovascular diseases. BMJ Open, 3(7). https://doi.org/10.1136/bmjopen2013-002817

18. Lim, S. M., Choi, D. P., Rhee, Y., \& Kim, H. C. (2015). Association between obesity indices and insulin resistance among healthy Korean adolescents: The JS High School study. PLOS ONE, 10(5), $1-12$. https://doi.org//0.137//journal.pone.0125238 
19. Lukács, A., Kiss-Tóth, E., Csordás, Á., Sasvári, P., \& Barkai, L. (20I8). Screening risk factors for type 2 diabetes in overweight and obese adolescents in school settings of Hungary: A population-based study. Journal of King Saud University - Science, $30(2)$, 176-179. https://doi.org/10.1016/j.jksus.2017.01.006

20. Qifti, F., Malini, H., \& Yetti, H. (2020). Karakteristik Remaja SMA dengan Faktor Risiko Diabetes Melitus di Kota Padang. Jurnal Ilmiah Universitas Batanghari Jambi, 20(2), 560. https://doi.org// 0.33087/jiubj.v20i2.950

21. Wabitsch, M., Hauner, H., Hertrampf, M., Muche, R., Hay, B., Mayer, H., Kratzer, W., Debatin, K. M., \& Heinze, E. (2004). Type II diabetes mellitus and impaired glucose regulation in Caucasian children and adolescents with obesity living in Germany. International Journal of Obesity, 28(2), 307-3 | 3. https://doi.org//0.1038/sj.ijo.0802555

22. Julia, M., Utari, A., Moelyo, A., \& Rochmah, N. (2015). Konsensus Nasional Pengelolaan Diabetes Mellitus Tipe 2 pada Anak dan Remaja.

23. DeFronzo, R. A., Ferrannini, E., Groop, L., Henry, R. R., Herman, W. H., Holst, J. J., Hu, F. B., Kahn, C. R., Raz, I., Shulman, G. I., Simonson, D. C., Testa, M. A., \& Weiss, R. (20I5). Type 2 diabetes mellitus. Nature Reviews Disease Primers, I(July). https://doi.org/10.1038/nrdp.2015.19

24. Lascar, N., Brown, J., Pattison, H., Barnett, A. H., Bailey, C. J., \& Bellary, S. (2018). Type 2 diabetes in adolescents and young adults. The Lancet Diabetes and Endocrinology, 6(I), 69-80. https://doi.org/10.1016/S2213-8587(17)30186-9

25. Dabelea, D., Stafford, J. M., Mayer-Davis, E. J., D’Agostino, R., Dolan, L., Imperatore, G., Linder, B., Lawrence, J. M., Marcovina, S. M., Mottl, A. K., Black, M. H., Pop-Busui, R., Saydah, S., Hamman, R. F., Pihoker, C., Koebnick, C., Reynolds, K., Holmquist, K., Li, X., ... Pierce, J. (2017). Association of type I diabetes vs type 2 diabetes diagnosed during childhood and adolescence with complications during teenage years and young adulthood. JAMA - Journal of the American Medical Association, 3/7(8), 825-835. https://doi.org/10.1001/jama.2017.0686
26. Chatterjee, S., Khunti, K., \& Davies, M. J. (2017). Type 2 diabetes. The Lancet, 389(10085), 2239225I. https://doi.org//0.1016/S01406736(17)30058-2

27. Decroli, E. (2019). Diabetes Mellitus Tipe 2. Pusat Penerbitan Bagian Ilmu Penyakit Dalam Fakultas Kedokteran Universitas Andalas.

28. Temneanu, O., Trandafir, L., \& Purcarea, M. (2016). Type 2 diabetes mellitus in children and adolescents: a relatively new clinical problem within pediatric practice. 9(3), 235-239.

29. Mansyah, B., \& Rahmawati, F. (202I). The Effectiveness of Audio-Visual Health Education Media on Diet on The Level of Knowledge and Attitude of Adolescent in the Prevention of Type 2 Diabetes Mellitus. Media Keperawatan Indonesia, 4(I), I. https://doi.org/I0.267I4/mki.4.I.202I.I-8

30. Fatimah, R. N. (20I5). Diabetes Melitus Tipe 2. DIABETES MELITUS TIPE 2, 4(5), 93-10I. Restyana Noor Fatimah Medical Faculty, Lampung University Abstract, Vol 4, 93-I0I. 